\title{
Female Genital Mutilation as Violence Against Women: A Narrative of Promoting Abandonment
}

\author{
Rizky Akbar Idris \\ University of Indonesia, Indonesia \\ Muhammad Pramadiathalla \\ University of Indonesia, Indonesia
}

\author{
Tania Daniela* \\ University of Indonesia, Indonesia
}

\begin{abstract}
Today, women and girls are less likely to undergo female genital mutilation (FGM) than decades ago. However, the practice is still near-universal in some countries. FGM is still practiced because societies still hold their traditional values and norms. According to UNICEF, at least 200 million women and girls have been subjected to the practice in 30 countries, mainly those in Asia and Africa. This study aimed to analyze FGM as violence against women relating to the communities and their beliefs by addressing the status quo and the legality of FGM practices in Indonesia, Egypt, and Yemen. It accounted for the state's role in preventing, handling, and safeguarding the victims of FGM practices. This study used the socio-legal method by critically analyzing the legislation for further implications for legal subjects. This study showed that FGM was a form of violence against women which have a role in the perpetual violation of women's rights. It identified the difference in practice, prevalence, legality, and the state's role in FGM in Indonesia, Egypt, and Yemen. It suggested to prevent FGM practices through mobilizing political will and funding, strengthening healthcare providers' awareness and knowledge, building a supportive legislative and regulatory environment, and reinforcing monitoring, evaluation, and accountability.
\end{abstract}

KEYWORDS: Women's Rights, Female Genital Mutilation, Violence Against Women.

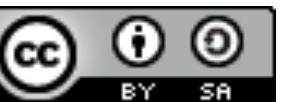

Copyright @ 2021 by Author(s)

This work is licensed under a Creative Commons Attribution-ShareAlike 4.0 International License. All writings published in this journal are personal views of the authors and do not represent the views of this journal and the author's affiliated institutions.

\section{HOW TO CITE:}

Idris, Rizky Akbar, et al., "Female Genital Mutilation as Violence Against Women: A Narrative of Promoting Abandonment" (2021) 2:2 Indonesian Journal of Law and Society 121-144, online: $<$ https://doi.org/10.19184/ijls.v2i2.24565>.

Submitted: 10/06/2021 Reviewed: 19/07/2021 Revised: 13/09/2021 Accepted: 14/09/2021

\footnotetext{
*Corresponding authors' e-mail: dnltania@gmail.com
} 


\section{INTRODUCTION}

Female genital mutilation (FGM) is violence against women manifested due to patriarchal culture. It is any procedure or action aimed at removing part or all of the external genital organs of a woman in the name of culture, custom, religion, or other reasons other than health or healing reasons. ${ }^{1}$ FGM is practiced for cultural, customary, or religious reasons rather than health reasons. It is included in violence against women because the practice violates women's rights. It subsequently becomes a form of violence against women. ${ }^{2}$ It can cause severe physical and mental health impacts, especially for girls and women. ${ }^{3}$ In addition, FGM also can cause complications, either directly or in the long term. ${ }^{4}$ FGM is a phenomenon that has been rife in many countries, particularly those in Africa and Asia. According to UNICEF, FGM affects at least 200 million women and girls in 30 countries. ${ }^{5}$ The types practiced among countries vary by location, ethnicity, and customs. However, around 90\% of FGM cases include clitoridectomy or excision, with the remaining $10 \%$ including infibulation, which has the most severe repercussions. ${ }^{6}$ It is still carried out based on traditions and social norms to ensure that women can be accepted into society and married and uphold the family's status and honor. ${ }^{7}$

This study focuses on FGM in Indonesia, Egypt, and Yemen. These are Muslim majority countries whose beliefs are mainly why FGM is practiced. Nevertheless, the government's and the people's stance on the issue presently differ from one country to another. FGM in Indonesia is primarily rooted in its customs and religious beliefs. The Indonesian

1 Sulistyowati Irianto, Perempuan E Hukum: Menuju Hukum yang Berperspektif Kesetaraan dan Keadilan (Jakarta: Yayasan Obor Indonesia, 2006) at 490.

2 Siti N Hodijah, et al., Persimpangan Antara Tradisi dan Modernitas Hasil Kajian Kualitatif Praktik Pemotongan/Pelukaan Genitalia Perempuan (P2GP) di 10 Provinsi 17 Kabupaten/Kota (Komnas Perempuan, 2018) at 75.

3 Female Genital Mutilation in Malta: a Research Study (NCPE, 2013).

4 UNICEF, Statistical Profile On Female Genital Mutilation/Cutting (New York: UNICEF, 2016) at 1.

5 Ibid.

6 WHO, Understanding and Addressing Violence Against Women: Female Genital Mutilation (World Health Organization, 2012).

7 UNICEF, supra note 4 at 1. 
government has not made any significant efforts to suppress FGM because of pressures from fundamentalist Muslims. FGM in Egypt has been prevalent since the days of pharaohs in Ancient Egypt and continues because of religious or cultural reasons. Although the Egyptian government has passed legislation prohibiting FGM, its practice remains in Egypt. Concurrently, FGM in Yemen has faced some decrease in popularity among its populace. However, the Yemeni government's efforts to ban FGM face some resistance from the conservative groups in the parliament.

This study aimed to analyze FGM as violence against women relating to the communities and their beliefs by addressing the status quo and the legality of FGM practices in Indonesia, Egypt, and Yemen. It accounted for the state's role in preventing, handling, and safeguarding the victims of FGM practices. This study develops an alternative, by focusing on the legal measures that the Indonesian government can take to promote the abandonment of FGM practices. Then, the government should establish a legal framework to promote the FGM abandonment and a supportive legal and educational framework with national guidelines and policies to guide all types of healthcare providers.

This study consists of two parts of the discussion. The first part deals with the overview of FGM as violence against women with the following practices in several countries, such as Indonesia, Egypt, and Yemen. The second part analyzes FGM issues, followed by the way in promoting the FGM abandonment.

\section{METHODS}

This study used the socio-legal method, which conducted contextual studies in which legislations were critically analyzed and explained for further implications for legal subjects. This research was examined through library or literature materials by collecting and reviewing primary and secondary legal materials in legislation and literature relevant to the research object. The analysis used was descriptive, which described the phenomenon under study. The analysis was carried out by connecting the cause and effect with the phenomenon's emergence under study. 


\section{FGM: WHAT IT IS AND WHY IT CONTINUES}

\section{A. FGM as Violence Against Women}

The World Health Organization (WHO) defines FGM, commonly known as female circumcision in Indonesia, as "any procedure that partially or completely removes the external genitalia, or injures the female genital organs for non-medical reasons." ${ }^{\text {A }}$ According to WHO, FGM is classified into four types. The first type involves the partial or complete removal of the clitoris, also known as clitoridectomy; follows. ${ }^{9}$ The second type is excision, defined as partial or total excision of the clitoris and labia minora, with or without cutting the labia majora. ${ }^{10}$ The third type is infibulation, a narrowing of the vaginal entrance caused by forming a septum. The septum is created by suturing the labia minora or majora and cutting or changing their shape, with or without clitoridectomy. ${ }^{11}$ The fourth type is all sorts of non-medical harm being done to the female genital organs, such as piercing, incising, and rubbing something into the vaginal area. ${ }^{12}$

Violence is frequently perpetrated against women or used as a form of oppression against women. It gave rise to new terminology, namely genderbased violence. The definition of 'gender-based violence' refers to the General Recommendation of the Convention on the Elimination of All Forms of Discrimination Against Women (CEDAW) Number 19 Point 1. It states as follows:

"Gender-based violence is a form of discrimination that seriously inhibits women's ability to enjoy rights and freedoms based on equality with men." ${ }^{13}$

8 WHO, Eliminating FGM: An interagency statement ONHCHR, UNAIDS, UNDP, UNECA, UNESCO, UNFPA, UNHCR, UNICEF, UNIFEM, WHO (Geneva: World Health Organizaton, 2008) at 1.

9 WHO, Types of FGM, online: World Health Organization <https://www.who.int/ teams/sexual-and-reproductive-health-and-research/areas-of-work/female-genitalmutilation/types-of-female-genital-mutilation>.

${ }^{10}$ Ibid.

${ }^{11}$ Ibid.

${ }^{12}$ Ibid.

${ }^{13}$ United Nations, Convention on the Elimination of All Forms of Discrimination Against Women, 3 September 1981 (General Recommendations No. 19, on article 1, 
This definition provides a common understanding of gender-based violence globally. Gender-based violence is essentially related to the lack of awareness of women's human rights. It includes all types of violence based on gender differences that result in or will cause pain or suffering to women, including threats, coercion, restrictions on freedom both in the public and domestic arenas. ${ }^{14}$ Violence against women occurs due to gender inequality, the condition of unequal relations between women and men, and is characterized by a less effective and robust relationship between the two. Various violence against women cannot be separated from the context of patriarchal cultural values and views, which always position women as objects and are on the side of the oppressed where it has entered all life structures. ${ }^{15}$ This culture shackles women's freedom to play an active role and contribute to society. The patriarchal culture also causes men's dominance in society's social structure to justify the oppression of women.

As a manifestation of patriarchal culture, FGM is carried out to control women's sexuality and social life, which violates women's fundamental rights and freedoms as human beings. It encourages women discriminated against based on gender. Then, it has violated women's health rights because it removes women's body parts needed for the satisfaction and security of their sex life. It violates the highest standards for physical and mental health that women have. There is a health risk from the implementation of FGM, namely death. ${ }^{16}$ In addition, it has explicitly violated the right to life because humans (women) should be free to determine their own lives. However, it is never based on involving women who do it (because most of it is done at the age of children). ${ }^{17}$ Then, it is

paragraph 1, of the Convention on the Elimination of All Forms of Discrimination Against Women, on violence against women, para. 1.)

14 Rifka Annisa, Tindak Pidana Kekerasan terhadap Perempuan dan Anak (Yogyakarta: Rifka Annisa Women's Crisis Centre, 2006) at 1.

${ }^{15}$ Muhammad R A Farid, "Kekerasan terhadap Perempuan dalam Ketimpangan Relasi Kuasa: Studi Kasus di Rifka Annisa Women’s Crisis Center” (2019) 14:2 Jurnal Studi Gender at 179-180.

16 Marlianda O Erwanti, "Kajian Yuridis FGM (FGM) Dalam Perspektif Hak Asasi Manusia (Studi terhadap Praktik FGM di Indonesia)" (2012) 1:4 Diponegoro Law Review at 7.

17 Komnas Perempuan, supra note 4 at 76. 
also thick with the power relationship between children and their parents. This inequality makes FGM continue to be carried out even if the woman says no to its practice. ${ }^{18}$

FGM violates not only women's rights but also children's rights. FGM can potentially inflict violence and exploitation of children because of the power of parents over the child's body which seems limitless. In cases of violence and exploitation of children in the family, most of the cases occurred because the authority of parents over their children seems limitless. Based on this authority, parents can argue that they have the right and authority to determine. While the girl has no control over her own body until her body has been defined and controlled through a set of traditions such as FGM. It is considered unfair because it is carried out toward baby girls who have not expressed their own opinion about how they want their bodies to be treated. So what happened later, children were 'forced' to accept FGM treatment in the name of religion and culture/tradition. The FGM tradition is not under the principles of giving freedom to children (child liberation), where children's rights are interpreted as giving freedom to children as independent individuals. By doing FGM on girls, a child is not a subject of rights. If a child no longer has the right to herself, then the potential for violence and exploitation is even more significant. In this context, the FGM tradition is contrary to the principles of child protection, especially for girls. ${ }^{19}$ Therefore, FGM is a form of violence against women that endangers and robs women and girls of their rights. ${ }^{20}$ Nevertheless, FGM is still carried out because it is based on traditions and social norms to ensure that women can be accepted into society and married and uphold the family's status and honor. ${ }^{21}$

18 Komnas Perempuan, Kertas Konsep Pencegahan dan Penghapusan Pemotongan/ Pelukaan Genitalia Perempuan (P2GP) (Jakarta: Komnas Perempuan, 2019) at 20.

19 Jauharotul Farida, et al., "Sunat Pada Anak Perempuan (Khifadz) dan Perlindungan Anak Perempuan di Indonesia: Studi Kasus di Kabupaten Demak" (2017) 12:1 Sawwa at 390-391.

20 Komnas Perempuan, supra note 4 at 77.

${ }^{21} \mathrm{WHO}$, supra note 6 at 1. 


\section{B. FGM Practices in Several Countries}

This study primarily delves into FGM practices in Indonesia, Egypt, and Yemen. The similarity between these countries is that they all have a majority of Muslims among their population, whose beliefs are the reason FGM is practiced, to begin with. ${ }^{22}$ Still, the government's position and the people on the issue of FGM are different in each country.

\section{Indonesia}

In Indonesia, FGM is more typically referred to as "female circumcision." This is because the practice of female circumcision in Indonesia does not necessarily fall into FGM forms, as suggested by the WHO. Female circumcision often does not entail removing a portion or most of the clitoris of the female genitalia in Indonesia. The practice of female circumcision is performed in a variety of methods according to the community's customs and culture, yet based on Basic Health Research (Riset Kesehatan Dasar) held in 2013 by the National Institute of Health Research and Development. It was part of the Health Ministry, the WHO classifies FGM in Indonesia into first and fourth types. ${ }^{23}$ Symbolic circumcision (symbolic only gestures) and circumcision with little actual cutting are the two forms of female circumcision practiced in various parts of Indonesia. ${ }^{24}$ An example of symbolic circumcision is practiced in Java. In Java, FGM is performed symbolically by touching something to the female genitalia, which is done by placing turmeric on the girl's clitoris, cutting or slicing the tumeric, and then throwing the turmeric pieces into the sea or burying them. ${ }^{25}$ It is different from the circumcision performed by cutting a small portion of the female genitalia. It is like removing a tiny part of the clitoris with a razor by a dukun (shaman), the community's elder, and

22 Ibid.

23 Komnas Perempuan, supra note 4 at 3.

24 Basilica D Putranti, "To Islamize, Becoming a Real Woman or Commercialized Practices? Questioning Female Genital Cutting in Indonesia” (2008) 3:2 Finnish Journal of Ethnicity and Migration at 26.

25 Komnas Perempuan, supra note 4 at 26. 
practicing circumcision, as the Sasak tribe Sumbawa practiced. ${ }^{26}$ Each practice of FGM can be regarded and accepted differently in the community. It occurs, and as a result, FGM continues to be practiced.

FGM has existed across generations for a long time because of the strong heritage of community cultural values, religions, and other beliefs. Communities of Indonesia believes that it has several aims, to be specific, to maintain purity, health, and beauty of women's bodies ${ }^{27}$, to exert control over women's sexuality and reproduction ${ }^{28}$, to preserve the status quo of unequal and unjust gender relations ${ }^{29}$, and religious purposes. ${ }^{30}$ Because of these aims, members of the community, especially parents, are pressured by society to circumcise their female children. For example, the Muslim community reinforces it, particularly in Jambi, where it is performed under Muslim traditions and religious guidance. ${ }^{31} \mathrm{~A}$ similar situation occurs in West Sulawesi, where females are obliged to be circumcised. Circumcision is considered a marking of a Muslim woman both in the world and in the afterlife. ${ }^{32}$ Subsequently, there are also views in some communities that believe if women do not have their genitalia circumcised, God will not recognize or accept their worship.

In addition to achieving religious aims, FGM has a function in defining the desired expression of sexuality in conformity with the gender roles established in society. ${ }^{33}$ It acts as an instrument to restrict individual sexual activity and create a feminine image and a sense of powerlessness in women. ${ }^{34}$ Some Muslims believe that female child who is not circumcised will grow up to be debauched or degenerate women. ${ }^{35}$ Negative stigmas

${ }^{26}$ Ibid.

27 Agus Hemanto, "Khitan Perempuan Antara Tradisi dan Syari'ah" (2016) 10:1 Kalam: Jurnal Studi Agama dan Pemikiran Islam at 268.

$28 \quad$ Ibid at 267.

${ }^{29}$ Ibid.

30 Ibid at 269.

31 Komnas Perempuan, supra note 4 at 119.

32 Ibid at 121-122.

33 Basilica D Putranti, "Sunat Perempuan: Cerminan Bangunan Sosial Seksualitas Masyarakat Yogyakarta dan Madura" (2005) 16:1 Populasi at 97.

34 Ibid at 98.

35 Ibid. 
such as wicked, nasty, and impure women linked to these women being cast off by the community encourage families, particularly parents, to circumcise their daughters. In Indonesia, FGM has become such a common and ongoing practice, and there is generally little discussion about the advantages or drawbacks of FGM on girls.

There is a misconception when FGM is associated with religious reasons. Any religion, notably Islam, never requires the FGM practices. There are no explicit or even implied norms in the Quran that mandates FGM. Based on the study of some researchers, it as a tradition is indivisible from the stigma about women in a patriarchal culture. To put it another way, the question about FGM in society should be addressed not merely as a question of religion or traditional customs but as part of a more significant attempt to perpetuate a patriarchal culture and gender bias in favor of men. ${ }^{36}$

The FGM legitimacy in Indonesia is noticeable in several regulations, one of which is the Minister of Health Regulation 1636/2010 issued by the Health Ministry, which became the legal grounds for FGM enforcement in Indonesia. In this regulation, FGM is defined as scratching the skin that covers the front of the clitoris without hurting the clitoris itself. ${ }^{37}$ FGM in Indonesia can only be performed by certain healthcare professionals, such as doctors, midwives, and nurses, who are licensed or permitted to practice, and preferably of the female gender. ${ }^{38}$ It can only be performed with the consent and request of the circumcised woman, her parents, and/or guardians. ${ }^{39}$ Under this regulation, the act of injuring the female genitalia by healthcare professionals may be carried out in the name of ensuring the safety of the circumcised woman. ${ }^{40}$ This regulation gave permissibility to the FGM practices and has become a guideline for healthcare professionals to perform FGM. ${ }^{41}$

\footnotetext{
36 Hemanto, supra note 27 at 270.

37 Regulation of the Minister of Health No.1636/MENKES/PER/XI/2010.

38 Ibid.

39 Ibid.

40 Komnas Perempuan, supra note 19 at 2

41 Komnas Perempuan, supra note 4 at 76.
} 
This $\mathrm{MOH}$ Regulation comes into existence as a result of pressure from the community. One of them is the Fatwa of the Indonesian Ulema Council (MUI), which response to the Circular Letter of the DirectorGeneral of Public Health HK.00.07.1.3.1047/2006 on the Prohibition of Medicalization of Female Circumcision. Then, the MUI issued Fatwa 9A/2008 on the Prohibition of Circumcision of Women. The Fatwa states that circumcision for both men and women is the nature and syiar of Islam. Female circumcision is a makrumah understood as one of the recommended forms of worship. ${ }^{42}$ This Fatwa stresses that female circumcision is imperative in Islam and must not be forbidden, and its prohibition is against Islamic Sharia. ${ }^{43}$

The government issued MOH Regulation 6/2014 that revoked Minister of Health Regulation 1636/2010 on Female Circumcision. Although its repeals MOH Regulation 1636/2010, FGM remains legal in Indonesia under this regulation. Article 2 mandates the Health and Syara'k Advisory Council to develop guidelines for female circumcision that safeguard the health and safety of circumcised women. ${ }^{44}$ However, the mandate of this article has remained unfulfilled until today. Thus, the legality of FGM practices is still ambiguous in Indonesia. This regulation shows an uncertain and hesitant stance of the government about the problem of FGM. The lack of a definite policy on the subject of FGM demonstrates that the government is not truly committed to tackling the problem. ${ }^{45} \mathrm{It}$ resulted in the continuation of FGM practices in Indonesia. ${ }^{46}$

42 Fatwa on the Law on the Probibition of Female Circumcision, SOR/2008-9A.

43 Medicalization of FGM in Indonesia, by Terres De Femmes \& Watch Indonesia (Terres De Femmes \& Watch Indonesia).

${ }_{44}$ Regulation of the Minister of Health, supra note 37.

45 Komnas Perempuan, supra note 4 at 78.

46 Ika, "Praktik Sunat Perempuan Masih Banyak Ditemukan di Indonesia", Universitas Gadjah Mada, online: <https://ugm.ac.id/id/berita/18994-praktik-sunat-perempuanmasih-banyak-ditemukan-di-indonesia $>$. 


\section{Egypt}

FGM is carried out in Egypt for several religious and cultural reasons. According to some studies, it has been practiced on Egyptian women and girls since pharaohs in ancient Egypt. Historical evidence suggests that it was first mentioned in the holy book of the Torah, brought by Moses. ${ }^{47}$ This tradition is believed to have been obeyed by the Israelites in the past. FGM in Egypt became known as a culture shared between Egyptians and Romans living in Egypt. It was once thought to be a method of eradicating a woman's masculine aspect in order for her to marry.

FGM practices in Egypt are usually performed in May and June, just before summer starts. The form of FGM practices is carried out in the first and second types. ${ }^{48}$ FGM has been prevalent in Egypt long before Christianity and Islam. Even though it does not stem from Islam and no norms are stating FGM in the Quran, the community typically invokes one of the hadiths that justify FGM on women. It is performed because it safeguards women's honor and virginity, which are highly esteemed and revered in Islam and are mandated in the Quran. ${ }^{49}$ One of the reasons for FGM in Egypt is that a social moral idea considers virginity to be the most treasured thing a woman has before she marries. Additionally, the purpose of FGM in Egypt is to reduce a woman's sexual urges, protecting them from sexual activity, thus maintaining their virginity. This idea causes women to be disadvantaged in preserving their honor and virginity because they have no say in their reproductive health choices. Furthermore, the rationale behind FGM practices in Egypt is to protect a family tradition predicated on the idea that women only become truly female after it has been performed on them, therefore removing their masculinity. Following this idea, when a woman undergoes FGM, she assumes her full status as a woman and distinguishes the positions of women and men in marriage.

47 Hemanto, supra note 27 at 265.

48 WHO, "Prevalence of Female Genital Cutting Among Egyptian Girls" (2008) 86:4 Bulletin of the World Health Organization at 270.

49 Marie B Assaad, "Female Circumcision in Egypt: Social Implications, Current Research, and Prospects for Change" (1980) 11:1 Studies in Family Planning at 5. 
These are the factors that have contributed to Egypt's persistent practice of FGM.

Although FGM in Egypt continues, there are legislative products with a women's standpoint to assure the protection and rights of women in Egypt. Egyptian lawmakers regulate such practices because FGM discriminates and results in injustice against women. ${ }^{50}$ The first regulation concerning FGM practices in Egypt was Law 126/2008, amended by Law 78/2016..$^{51}$ Law 78/2016 contains provisions prohibiting FGM. The punishment for FGM practices is more stringent than before. ${ }^{52}$ This regulation aimed to explicitly not accept it, promote its abandonment, and ban its conduct in Egypt. $^{53}$

The restriction against FGM may also be found in the Child Law 12/1996 as amended by Law 126/2008, which prohibited FGM against minors. ${ }^{54}$ The government must protect children's rights in all situations or provide a safe, healthy, and clean environment for them. The state must take decisive action to prevent harmful practices against children's health. The law further prohibits guardians or caregivers of children from exposing children to illegal physical violence or dangerous practices purposefully. ${ }^{55}$ Moreover, through Ministerial Decree Regulation, the Egyptian government bans FGM by medical practitioners by prohibiting nurses or doctors from cutting or modifying any part of the female genitalia, whether in public hospitals, private, or anywhere else. Violations of these rules will be viewed as a breach of the medical code of ethics, with potential criminal consequences. ${ }^{56}$ The Egyptian government's motivation for enacting this rule stems from many Egyptian women who have died due to FGM. For that reason, the need for a legal basis for the protection of women's rights

${ }^{50}$ UNICEF \& UNFPA, Tackling FGM/Cutting in Egypt 2010 (Egypt: UNICEF \& UNFPA, 2010).

51 George Sadek, Egypt: Sexual Violence Again Women, online: <https://www.loc.gov/ law/help/sexual-violence-against-women/egypt-sexual-violence-against-women.pdf>

52 Thomson Reuters Foundation \& 28 Too Many, Egypt: The Law and FGM (Thomson Reuters Foundation \& 28 Too Many, 2018).

${ }^{53}$ UNICEF \& UNFPA, supra note 50.

${ }^{54}$ Law Concerning Child Act, SE 2008.

55 Ibid.

${ }^{56}$ Thomson Reuters Foundation \& 28 Too Many, supra note 52. 
arises. As a result of laws prohibiting FGM and the establishment of the National Committee for Eliminating FGM in 2019, awareness among Egyptians on the dangers of FGM has risen, and more people are reporting illegal practices of FGM in the country. ${ }^{57}$

\section{Yemen}

FGM in Yemen mainly falls into type II under WHO's classification. Approximately 83 percent of FGM in Yemen is performed in this manner. ${ }^{58}$ In some parts of Yemen, another practice known regionally as altakmeed (compression) is conducted on the female genitalia. It comes in different forms. In some communities, a compress is used on the genitalia on the fourth day following the birth of a girl. The compress is made out of soft cotton cloth with heated salt or sand within oil and herbs, which then is placed on the girl's genitalia, repeatedly pressing it for about an hour. Then, this procedure is repeated for about 40 days and up to four months. This treatment is intended to reduce sexual excitement by damaging nerve endings in the female genitalia. ${ }^{59}$ In other places, different materials are used to produce the same effect. For example, a community in the AlMahra region of Yemen rubs the clitoris of girls with a piece of onion to attain cleanliness. ${ }^{60}$

The Demographic and Health and Health Survey (DHS) conducted by the Ministry of Public Health and Population in 2013 found that 19\% of all women aged 15 to 49 have had their genitalia circumcised in some way. ${ }^{61}$

57 UN Women, "As more families report FGM incidents in Egypt, advocacy intensifies, and a new bill seeks to increase penalties", online: <https://www. unwomen.org/en/news/stories/2021/2/feature--families-report-fgm-in-egypt-andadvocacy-intensifies $>$.

58 Human Rights Watch, Killing My Daughter Haunts Me: FGM in Yemen (United States of America: Human Rights Watch, 2015).

59 Husnia Al-Qaderi, "Situation Analysis on FGM/Cutting (FGM) in Yemen," (2008) at 4.

${ }^{60}$ Human Rights Watch, supra note 58.

61 Yemen Ministry of Public Health \& Population \& Central Statistical Organization, National Health and Demographic Survey 2013,( Preliminary Report) (Yemen: Yemen Ministry of Public Health \& Population \& Central Statistical Organization,2013) at 28. 
The prevalence of practice varies depending on the woman's level of education, suggesting that it may also be attributed to her parents' socioeconomic status. A survey found that over $22 \%$ of women with no education, $18 \%$ of women with primary education, and $11 \%$ of women with a secondary or higher education said they had been circumcised. Victims also said their fathers had little or no education, while their mothers had only primary school education. Surveys have also shown a trend of FGM becoming less prevalent among younger women. According to the 2013 DHS, less than $17 \%$ of women aged 15 to 29 were mutilated, relative to 21 to $23 \%$ of women aged 30 and older. As per a UNICEF survey from 2012, 19 percent of women under 20 are circumcised, whereas 23 to 25 percent of women aged 20 and beyond are circumcised. ${ }^{62}$

It is mainly driven by the idea that FGM is a religious responsibility and improves cleanliness. Although many families who circumcise their daughters claim a religious motive for the practice, government officials believe its true purpose is to repress girls' sexual desires. ${ }^{63}$ In Yemen, the roots of FGM stem from the Shafi'i school (maddhab) within Islam. Meanwhile, other schools such as Hanafi or Maliki do not practice FGM at all. Imams from the Shafi'i school push the FGM agenda in their sermons, referring to it as necessary. ${ }^{64}$

According to a survey held by the Yemeni government in 2003, only 32\% of Yemeni women said that FGM should continue. The research discovered tendencies based on the respondent's level of education and location where uneducated women were more supportive of FGM than educated women, and rural women were more supportive of FGM than urban women..$^{65} 68 \%$ of the women who rejected the practice stated it was a harmful tradition, and $41 \%$ stated it was against Islam. ${ }^{66}$ Studies also found

\footnotetext{
${ }^{62}$ Human Rights Watch, supra note 58.

63 Ibid.

${ }^{64}$ Ibid.

65 Ibid.

66 Ibid.
} 
a decline in FGM over the last decade. The number of support towards the practice also sees a drop in the people of Yemen. ${ }^{67}$

Concerning the legitimacy of FGM, there is presently no legal framework that expressly criminalizes and sanctions FGM in Yemen. ${ }^{68}$ However, various efforts have been made by the Yemeni government to bring an end to the practice. The Ministry of Public Health, for example, issued a ministerial decree prohibiting FGM treatments in government and private healthcare facilities in 2001. However, the decree did not impose punishments for noncompliance. The decree itself has difficulties in practice due to the difficulty of monitoring in healthcare facilities. ${ }^{69}$ To stop FGM practices, the Health Ministry introduced a bill to the Yemeni parliament that aimed to protect women's health, including provisions that would ban "Surgical procedures on a woman's genitalia" unless necessary for medical reasons. Members of parliament opposed the bill, claiming it was against Sharia law, which authorizes FGM. Unfortunately, the bill passed in the parliament but without the provision to ban FGM in Yemen. ${ }^{70}$

\section{ADDRESSING THE FGM ISSUES}

\section{A. The Issues Within FGM}

The lack of assertiveness of the government against FGM creates ambiguity in some elements of society. Regulation of the Minister of Health 6/2014 is an ambiguous attitude of the government because it only states to revoke the previous regulation, allowing health personnel to practice FGM. However, it did not clearly state the prohibition against FGM. Instead, it gave a mandate to the Health and Syara'k Advisory Council to make guidelines for implementing the 'safe' practice of FGM.

Only a few healthcare training schools have included extensive knowledge regarding FGM in their curricula. For example, the University of Sydney in

\footnotetext{
${ }^{67}$ Ibid.

68 FGM In Yemen: Short Report, by 28 Too Many (28 Too Many, 2020).

${ }^{69}$ Human Rights Watch, supra note 58.

70 Ibid.
} 
Australia evaluated the findings of 18 studies as part of their evaluation of FGM. ${ }^{71}$ While in the UK, The British Medical Association (BMA) published its first comprehensive FGM guidelines in 2011. ${ }^{72}$

In some countries, healthcare providers claim a lack of information about FGM and why it should be prohibited and technical understanding about caring for girls and women who have had FGM problems. ${ }^{73}$ With greater awareness of the adverse effects of FGM and greater healthcare access these days, there are attempts to medicalize FGM, having the operation performed by healthcare workers in clinical settings with the assumption that it is entirely safe. ${ }^{74}$ These campaigners of FGM medicalization claim that it will help decrease the procedure's risks, limit the extent of mutilation, and lessen the pain affiliated with it. Another common claim is that medicalization is the first process toward the abolishment of the practice. Also, because the healthcare industry has had limited participation in the preventive measures of FGM in women in the number of places where FGM is performed, structured coordination between prominent stakeholders at the national, grassroots, and health sectors should work nicely.

\section{B. Recommendations to Promote the FGM Abandonment}

Healthcare must not perform any form of FGM in any situation, and neither they perform infibulation upon delivery or in any circumstance. They must provide medical treatment for girls and women experiencing FGM complications, including proper care during pregnancy and birth for

71 University of Sydney, "Health Professionals Lack Knowledge About FGM", online: $<$ https://www.sydney.edu.au/news-opinion/news/2016/03/18/health-professionalslack-knowledge-about-female-genital-mutilat0.html>.

72 Female Genital Mutilation: Caring for patients and safeguarding children, by British Medical Association, BMA 51999/AB/ETHICS/JULY 2011 (British Medical Association, 2011).

73 Global strategy to stop healthcare providers from performing female genital mutilation, by World Health Organization, WHO/RHR/10.9 (World Health Organization, 2010) at 10 .

74 WHO, Policy Guidelines for Nurses and Midwives WHO/FCH/GWH/01.5 (Geneva: World Health Organization, 2001). 
women who have previously undergone FGM. They should educate women who may have endured the effects of FGM, along with their families, and inform them to receive treatment for their problems and mental health consequences, to prevent infibulation, and to reject having FGM performed on their daughters or other family members. Healthcare providers must also act as community activists for the practice's elimination. Healthcare providers need to use their competence and authority to promote girls' and women's health and human rights, notably their rights to information, personal rights, freedom from violence, and health. ${ }^{75}$

FGM-performed healthcare providers are hardly brought to the notice of the higher authorities for professional disciplinary and/or legal action. ${ }^{76}$ While legal actions alone commonly result in secret operations or initial disobedience, a legal framework for women's and girls' human rights is essential. When applied in combination with community-based work, a framework that incorporates preventive efforts to promote abandonment and punitive actions for those who partake in practice has been found to have a better impact.

The government should develop strategies and formulate specific plans of action based on particular circumstances through a collaborative process that involves all stakeholders. UNICEF has the specific strategy for the elimination of FGM includes the following six pillars. The first is developing and implementing policies and legislation that protect the rights of girls and women. ${ }^{77}$ The second is to increase girls' agency and assets and build their leadership skills to influence social change. The third is to shift discriminatory social and gender norms through community-led mobilization. The fourth is to strengthen child protection systems to ensure access to essential services. The fifth is to build a robust evidence base. The sixth is the humanitarian-development nexus: a cross-cutting approach to FGM elimination.

75 Ibid.

76 Ibid.

77 UNICEF, A Decade of Action to Achieve Gender Equality: The UNICEF Approach to the Elimination of FGM, UNICEF/UNI308798/Tadesse (UNICEF, 2020). 
Out of the countries that practiced FGM, as mentioned before, Egypt has succeeded in its multi-layered strategy to eliminate FGM in the country. The Egyptian Cabinet recently approved the draft law submitted by the National Committee for the Eradication of FGM by amending some provisions of the Penal Code issued by Law 58/1937 to decide a deterrent punishment for those who practice FGM. ${ }^{78}$

\section{Legal Theories on Social Regulation}

Legal theories of social control are frequently described as belonging to one of two ideologies: law and economics and law and society. Both study the relation between informal local social control and the formal legal system controlling human behavior but vary in the primacy given each one. ${ }^{79}$

The law and economics movement argues that the state essentially achieves social control through the legal system and that governments are the primary providers of regulations and enforcement tools. ${ }^{80}$ The law and economics movement emphasizes the significance of incentives and their power to influence behaviors. It implies that people are logical and forward-thinking and will adjust their behaviors in the face of legal incentives. An anticipated utility calculation determines whether or not a person performs an unlawful behavior. Therefore, based on the law and economics perspective to FGM predictions, it may be expected that the law forbidding FGM is valid and enforceable. Also, if we consider the costs and advantages of the practice, legal sanctions may play a role in the equation in a powerful way. For some, the prospect of increased financial expenses motivates their choice to end FGM. Egypt used this study by

78 Egyp Today Staff, "What you need to know about Egypt's efforts to eradicate FGM", Egypt Today (5 February 2021), online: <https:/www.egypttoday.com/ Article/6/98252/What-you-need-to-know-about-Egypt $\%$ E2\%80\%99s-efforts-toeradicate $>$.

79 Irving M Zeitlin, "Max Weber's Sociology of Law” (1985) 35:2 The University of Toronto Law Journal at 183-214.

80 Posner R A, Economic Analysis of Law, 6th ed (New York: Aspen Publishers, 2003). at 31 . 
imposing a law that focuses on deciding a deterrent punishment for those who practice it in the hope of permanently ending the practice.

Meanwhile, law and society academics argue that the fear of criminal prosecution has a limited influence in some cases. They stress that regulations enforced at the local level frequently contradict formal regulations but adhere to commonly held beliefs about proper behaviors and practices. Social group's influence can be significant as there are significant social penalties, such as withholding or awarding signs of status and respect or restricting access to material resources. ${ }^{81}$ Thus, the law and society movement believe that both law and social norms influence behaviors but that substantive norms frequently complement, and at times overrule, formal laws. ${ }^{82}$ In terms of FGM, individuals may have limited issues about the enforceability of the legislation prohibiting it due to a lack of understanding of the legal requirement. Furthermore, the legislation prohibiting FGM may not drive the procedure's elimination but rather may encourage the practice's illegal practice.

\section{CONCLUSION}

FGM is a form of violence against women that endangers and robs women of their rights. In contrast, it is still carried out by considering traditions and social norms to ensure that women can be accepted into society and married and uphold the family's status and honor. It has been practiced for a long time due to a strong history of community cultural values in Indonesia, Egypt, and Yemen. In Indonesia, the government never clearly states the prohibition against FGM. The 'void' of the regulation regarding FGM in Indonesia reflects an ambiguous attitude of the government since the MOH Regulation 6/2014 only states to revoke the previous regulation, which allowed healthcare providers to practice FGM. While in Egypt, the Cabinet recently approved a draft law submitted by the National Committee to eradicate FGM to impose harsher penalties for those

81 Ibid.

82 Bettina Shell-Duncan, et al., "Legislating Change? Responses to Criminalizing Female Genital Cutting in Senegal" (2013) 47:4 Law \& Society Review at 57-71. 
practicing FGM. Compared to previous countries, the Yemen parliament passed a bill that would ban FGM without banning FGM in the country. Even before the bill passed, the members of the Yemeni parliament opposed the bill claiming it was against Sharia law which authorizes FGM in Yemen. Therefore, the government should also establish a proper legislative and educational framework and correlating national guidelines and policies to guide the work of all types of healthcare providers, such as reporting and monitoring routines. It should also provide the necessary budget to prevent the medicalization of FGM inside the overall framework of complete abolition of the practice. Also, the government should guarantee that healthcare providers receive extensive training and learn the essential knowledge and abilities to care for girls and women suffering from FGM complications and enhance their capacity to campaign for the practice's elimination.

\section{ACKNOWLEDGMENTS}

None.

\section{REFERENCES}

A, Posner R, Economic Analysis of Law, 6th ed (New York: Aspen Publishers, 2003).

Annisa, Rifka, Tindak Pidana Kekerasan terhadap Perempuan dan Anak (Yogyakarta: Rifka Annisa Women’s Crisis Centre, 2006).

Assaad, Marie B, "Female Circumcision in Egypt: Social Implications, Current Research, and Prospects for Change" (1980) 11:1 Stud Fam Plann.

British Medical Association, Female Genital Mutilation: Caring for patients and safeguarding children, by British Medical Association, BMA 51999 /AB/ETHICS/JULY 2011 (British Medical Association, 2011).

Egyp Today Staff, "What you need to know about Egypt's efforts to eradicate FGM", Egypt Today (5 February 2021), online: <https:// 
www.egypttoday.com/Article/6/98252/What-you-need-to-knowabout-Egypt $\%$ E2\%80\%99s-efforts-to-eradicate>.

Erwanti, Marlianda O, "Kajian Yuridis FGM (FGM) Dalam Perspektif Hak Asasi Manusia (Studi terhadap Praktik FGM di Indonesia)" (2012) 1:4 Diponegoro Law Rev.

Farid, Muhammad R A, "Kekerasan terhadap Perempuan dalam Ketimpangan Relasi Kuasa: Studi Kasus di Rifka Annisa Women's Crisis Center" (2019) 14:2 J Studi Gend.

Farida, Jauharotul, et al., "Sunat Pada Anak Perempuan (Khifadz) dan Perlindungan Anak Perempuan di Indonesia: Studi Kasus di Kabupaten Demak" (2017) 12:1 Sawwa.

Hemanto, Agus, "Khitan Perempuan Antara Tradisi dan Syari'ah" (2016) 10:1 Kalam J Studi Agama Dan Pemikir Islam.

Hodijah, Siti N, et al., Persimpangan Antara Tradisi dan Modernitas Hasil Kajian Kualitatif Praktik Pemotongan/Pelukaan Genitalia Perempuan (P2GP) di 10 Provinsi 17 Kabupaten/Kota, by Siti N Hodijah et al (Komnas Perempuan, 2018).

Human Rights Watch, Killing My Daughter Haunts Me: FGM in Yemen, by Human Rights Watch (United States of America: Human Rights Watch, 2015).

Ika, "Praktik Sunat Perempuan Masih Banyak Ditemukan di Indonesia", Univ Gadjah Mada (February 2020), online: <https://ugm.ac.id/id/ berita/18994-praktik-sunat-perempuan-masih-banyak-ditemukan-diindonesia>.

Irianto, Sulistyowati, Perempuan \& Hukum: Menuju Hukum yang Berperspektif Kesetaraan dan Keadilan (Jakarta: Yayasan Obor Indonesia, 2006).

Komnas Perempuan, Kertas Konsep Pencegahan dan Penghapusan Pemotongan/Pelukaan Genitalia Perempuan (P2GP) (Jakarta: Komnas Perempuan, 2019). 
Putranti, Basilica D, "Sunat Perempuan: Cerminan Bangunan Sosial Seksualitas Masyarakat Yogyakarta dan Madura” (2005) 16:1 Populasi.

Putranti, Basilica D, "To Islamize, Becoming a Real Woman or Commercialized Practices? Questioning Female Genital Cutting in Indonesia" (2008) 3:2 Finn J Ethn Migr.

Shell-Duncan, Bettina, et al., "Legislating Change? Responses to Criminalizing Female Genital Cutting in Senegal" (2013) 47:4 Law Soc Rev.

Terres De Femmes \& Watch Indonesia, Medicalization of FGM in Indonesia (Terres De Femmes \& Watch Indonesia).

Thomson Reuters Foundation \& 28 Too Many, Egypt: The Law and FGM (Thomson Reuters Foundation \& 28 Too Many, 2018).

University of Sydney, "Health Professionals Lack Knowledge About FGM", online: <https://www.sydney.edu.au/news-opinion/news/ 2016/03/18/health-professionals-lack-knowledge-about-femalegenital-mutilat0.html>.

UN Women, "As more families report FGM incidents in Egypt, advocacy intensifies, and a new bill seeks to increase penalties", UN Women (5 February 2021), online: <https://www.unwomen.org/en/news/stories/ 2021/2/feature--families-report-fgm-in-egypt-and-advocacyintensifies>.

UNICEF, $A$ Decade of Action to Achieve Gender Equality: The UNICEF Approach to the Elimination of FGM, UNICEF/ UNI308798/Tadesse (UNICEF, 2020).

UNICEF, Statistical Profile On Female Genital Mutilation/Cutting (New York: UNICEF, 2016).

UNICEF \& UNFPA, Tackling FGM/Cutting in Egypt 2010 (Egypt: UNICEF \& UNFPA, 2010).

WHO, "Prevalence of Female Genital Cutting Among Egyptian Girls" (2008) 86:4 Bull World Health Organ. 
WHO, Understanding and Addressing Violence Against Women: Female Genital Mutilation, by WHO (World Health Organization, 2012).

WHO, Eliminating FGM: An interagency statement ONHCHR, UNAIDS, UNDP, UNECA, UNESCO, UNFPA, UNHCR, UNICEF, UNIFEM, WHO (Geneva: World Health Organizaton, 2008).

$\mathrm{WHO}$, Global strategy to stop healthcare providers from performing female genital mutilation, WHO/RHR/10.9 (World Health Organization, 2010).

WHO, Policy Guidelines for Nurses and Midwives, WHO/FCH/GWH/ 01.5 (Geneva: World Health Organization, 2001).

Zeitlin, Irving M, “Max Weber's Sociology of Law” (1985) 35:2 Univ Tor Law J.

28 Too Many, FGM In Yemen: Short Report (28 Too Many, 2020). 
144 | Female Genital Mutilation as Violence Against Women: A Narrative of Promoting Abandonment

This page intentionally left blank 